\title{
THE INFLUENCE OF TEMPERATURE IMPACT ON THE STRENGTH OF ADHESION OF POLYURETHANE GLUE- FOAM WITH MASONRY PRODUCTS
}

\author{
Valery Derkach ${ }^{{ }^{*}}$ \\ ${ }^{1}$ Brest State Technical University, 224017, Moskovskaya 267, Brest, Belarus
}

\begin{abstract}
The use of masonry on glued polyurethane foam joints can significantly increase labor productivity in the construction of stone buildings. One of the factors restraining the introduction of polyurethane foam adhesive into the practice of construction of stone buildings is insufficient knowledge of the influence of temperature effects on the adhesion of adhesive-foam to masonry products. In order to obtain data on the adhesion strength of polyurethane joints with masonry products under temperature influences, 28 prototypes of masonry were tested, aged in laboratory conditions and also subjected to heating to $100^{\circ} \mathrm{C}$ and $200^{\circ} \mathrm{C}$. Tests of masonry samples were carried out in accordance with STB EN 1052-5. Based on the experimental studies carried out and new data on the influence of temperature effects on the adhesion strength of polyurethane joints with masonry products were obtained.
\end{abstract}

Key words: masonry, polyurethane seams, adhesion strength, temperature influences.

\section{Introduction}

The introduction of innovative technologies in construction aimed at increasing labor productivity and reducing the cost of products is in line with the priorities, goals and objectives of the Program of socio-economic development of the Republic of Belarus for 2016-2020. Recently, a new technology for the production of masonry works on adhesive polyurethane foam (PPU) joints has been used in the construction of stone walls in the countries of the European Union [1-3]. Research work on the introduction of this technology in construction is currently being carried out in the Republic of Belarus [4-6].

Preliminary studies of the possibility of using the technology of polyurethane foam joints for masonry made of aerated concrete blocks which were carried out in Russia [7-9] show that when using polyurethane masonry mixtures the speed of work has doubled compared to masonry on cement mixtures, at the same time, taking into account the consumption and cost of polyurethane foam glue, the cost of masonry turned out to be lower. According to the results of heat engineering tests, the calculated value of the thermal resistance of a wall

\footnotetext{
* Corresponding author: v-derkatch@yandex.ru
} 
fragment with a thickness of $375 \mathrm{~mm}$ made of blocks of grade D400 density on polyurethane glue with an equilibrium weight moisture content of products in the masonry of $5 \% \mathrm{Rw} 1$ was $3.44 \mathrm{~m}^{2}{ }^{\circ} \mathrm{C} / \mathrm{W}$ (for comparison, the same thermal resistance for cement joints can be obtained for a wall thickness of $500 \mathrm{~mm}$ ). The fire resistance limit of a sample of a partition with a thickness of $100 \mathrm{~mm}$ made of autoclaved aerated concrete blocks with a density of D400, a compressive strength class B2, on a polyurethane foam glue was EI 150. Thus, preliminary tests confirm the feasibility of introducing the above technology in construction practice.

Polyurethane foam adhesive is an organic material that is subject to pyrolysis at certain temperatures, which can adversely affect the resistance of masonry to force effects during and after fire. Stone structures with polyurethane joints are usually used as floor-by-floor support external walls and internal partitions. Limiting state in such structures under force effects is determined by the shear strength of the masonry and tensile bending which essentially depend on the adhesion strength of mortar joints with masonry products. In this regard, the study of the effect of temperature effects on the adhesion strength of polyurethane foam glue with masonry products is an urgent and important task.

\section{Method}

The prototypes consisted of two masonry productsof of dense silicate concrete connected by means of a PPU seam. The width of the masonry products was $70 \mathrm{~mm}$, the length was $240 \mathrm{~mm}$. The supporting surfaces of the masonry products were wiped from dust after which one strip of polyurethane mixture was applied to them, on which the next masonry product was laid. Immediately after fabrication, the prototypes were compressed so that the compressive stresses in the cross section of the specimen were about $2.5 \cdot 10_{-}^{3} \mathrm{~N} / \mathrm{mm}^{2}$. In the loaded state, the samples were stored before testing for 7 days in laboratory conditions at a temperature of $+18^{\circ} \mathrm{C}$ $\square+20^{\circ} \mathrm{C}$ and an air humidity of $65 \%$.

4 series of prototypes of masonry were prepared for testing with a total of 28 samples. Series PI and PII included 9 prototypes, series PIII and PIV - 5 samples each. Samples of the PI series were tested after being in laboratory temperature conditions $-\mathrm{t}^{\circ}=20^{\circ} \mathrm{C}$. Samples of the PII series were tested after heating to $100^{\circ} \mathrm{C}$ and subsequent cooling to $20^{\circ} \mathrm{C}$ and samples of the PIII and PIV series after heating to $200^{\circ} \mathrm{C}$. The samples of the PIII series were tested after cooling down to $20^{\circ} \mathrm{C}$ and the samples of the PIV series were tested in a heated state. After heating, the prototypes were kept at a given temperature for 60 minutes. Heating of prototypes and holding in a heated state were carried out in a muffle furnace. After removing the samples from the furnace, their surface temperature was determined using a laser thermometer.

The tensile strength of the masonry in an unbound section (normal bond strength) was determined by the bending moment method in accordance with STB EN 1052-5 [10] (Figure 1).

The force on the masonry sample was transmitted using a P-10 laboratory test press equipped with an electronic device for recording the force. The loading rate was chosen such that fracture occurred within the range from 2 minutes to 5 minutes from the beginning of the load application. 


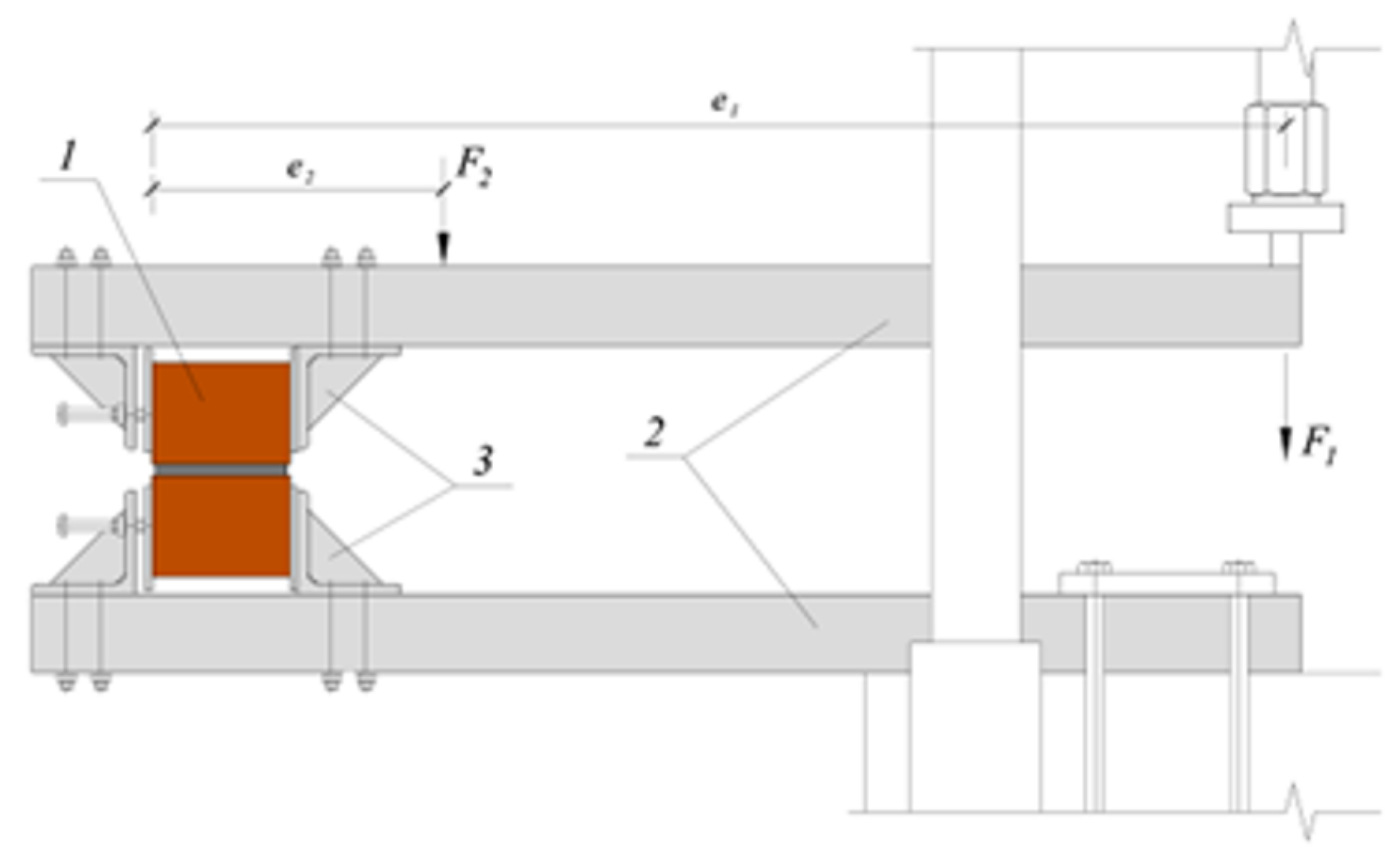

1 - test piece, 2 - levers, 3 - clamps

Figure 1. Scheme of prototype testing

For each case of fracture, the bond strength was calculated with an accuracy of up to $0.01 \mathrm{H} / \mathrm{mm}^{2}$ using formula (1).

$$
\begin{gathered}
f_{w i}=\frac{F_{1} e_{1}+F_{2} e_{2}-\frac{2}{3} d\left(F_{1}+F_{2}+\frac{W}{4}\right)}{Z} \\
Z=\frac{b d^{2}}{6}
\end{gathered}
$$

where:

- $b$ - average length of the tested horizontal weld in $\mathrm{mm}$;

- $d$ - the average width of the sample in $\mathrm{mm}$;

- $e 1$ - distance from the axis of the load application to the stretched face of the specimen in $\mathrm{mm}$;

- $e 2$ - the distance from the center of gravity of the lever and clamp to the stretched edge of the sample in $\mathrm{mm}$;

- F1 - applied load in $\mathrm{H}$;

- F2 - load from the weight of the lever and clamp in $\mathrm{H}$;

- $W$ - load from the weight of the top masonry product.

\section{Results and Discussion}

The destruction of most of the prototypes occurred as a result of the rupture of the PPU weld (Figure 2a). In some specimens, the tear off of the upper or lower masonry product along the adhesion boundary was observed (Figure $2 b$ ). 
a)

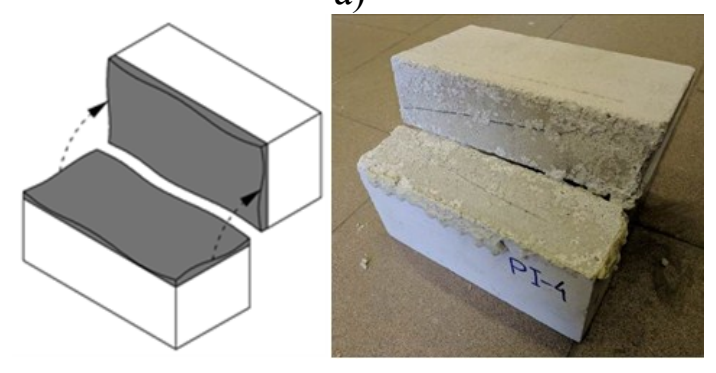

b)

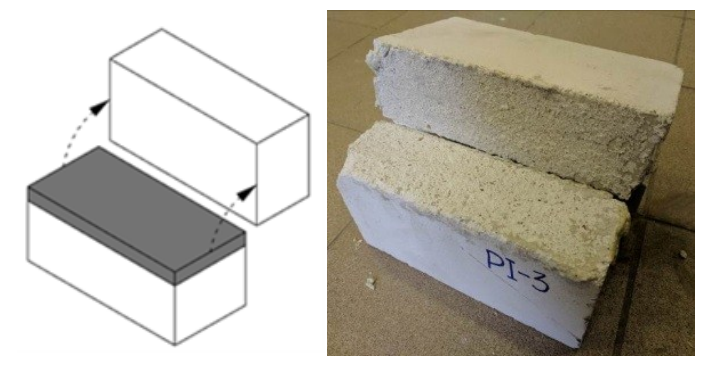

a) rupture of the PPU seam, b) tearing the PPU seam from the masonry product Figure 2. The nature of the destruction of prototypes

The average value of adhesion strength $\overline{f_{w}}$ of prototypes of the PI series, cured and tested in laboratory conditions, was $0.82 \mathrm{MPa}$ with a coefficient of variation $v=20 \%$. The average value $\overline{f_{w}}$ of the samples of the PII series, heated to $100^{\circ} \mathrm{C}$ and tested in the cooled state to $20^{\circ} \mathrm{C}$, turned out to be practically the same as for the samples of the PI series. When the prototypes were heated to $200^{\circ} \mathrm{C}$ and then cooled, the bond strength decreased, the average value of which was $0.68 \mathrm{MPa}$ at $v=19 \%$. A graphic interpretation of the results obtained is shown in Figure 3.

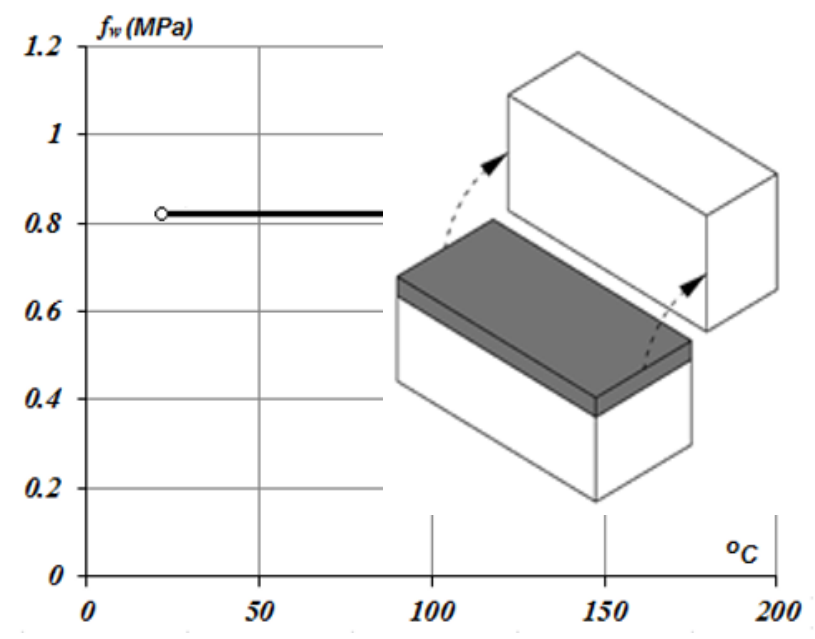

Figure 3 - Graph of the dependence of the strength of normal adhesion of polyurethane foam seam of temperature 
The lowest value of adhesion strength $\overline{f_{w}}$ was obtained when testing prototypes of the PIV series in a state heated to $200^{\circ} \mathrm{C}$. The value $\overline{f_{w}}$ of these samples was $0.3 \mathrm{MPa}$ which is 2.7 times lower than the adhesion strength of the PI series samples. It should be noted that in all cases the adhesion strength of polyurethane seams was no lower than when using thin-layer solutions based on mineral binders $(0.3 \mathrm{MPa})$ which indicates a high degree of fire safety of masonry with the use of polyurethane adhesive foam.

\section{Conclusion}

On the basis of experimental studies, new data were obtained on the effect of temperature effects on the adhesion strength of PPU seams with masonry products. It has been established that after heating the prototypes to $200^{\circ} \mathrm{C}$ and their subsequent cooling to $20^{\circ} \mathrm{C}$, the adhesion strength of PPU seams $f w$ decreases. The minimum value of adhesion strength took place when testing prototypes in a state heated to $200^{\circ} \mathrm{C}$. The value $f w$ of these specimens turned out to be 2.7 times lower than the adhesion strength of specimens aged and tested in laboratory conditions.

The results obtained should be considered as preliminary. More complete data on the effect of temperature on the mechanical characteristics of masonry on polyurethane foam joints can be established on the basis of experimental studies of stone walls exposed to temperature effects in a standard fire.

\section{References}

1. A. Jäger, Verklebung von Planziegelmauerwerk mit Polyurethanklebern [Joining in masonry with polyurethane adhesives] / A. Jäger, C. Kuhlemann, E. Habian, M. Kasa, S. Lu // Mau-erwerk. - № 15. - pp. 223-231 (2011)

2. E. Aldoghaim, Untersuchungen zur Verbesserung der mechanischen Eigenschaften von Mauerwerk durch Elastomerlager [Studies of the mechanical properties of masonry on elastic joints]/ E. Aldoghaim // Mauerwerk. - № 16. - pp. 93-102 (2012)

3. R. Drobiec, Wplyw rodzaja zaprawy na parametry mechaniczne murow $\mathrm{z} A B K$ poddanych sciskaniu [Influence of the type of mortar on the mechanical characteristics of ABK masonry under compression] / R. Drobiec, R. Jasinski // Materialy Budowlane. - №4. - pp. 3-7 (2015)

4. V.N. Derkach, Strength and deformability of masonry from autoclaved aerated concrete blocks on polyurethane seams. Part 1. Strength and deformability in compression / V.N. Derkach // Building materials. - No. 5. - pp. 29-33 (2017)

5. V.N. Derkach, Strength and deformability of masonry from autoclaved aerated concrete blocks on polyurethane seams. Part 2. Tensile strength in bending / V.N. Derkach // Building materials. - No. 7. - pp. 30-34 (2017)

6. V.N. Derkach, Strength and deformability of masonry from autoclaved aerated concrete blocks on polyurethane seams. Part 3. Strength and deformability during shear / V.N. Derkach, IE Demchuk // Building materials. - No. 8. - pp. 32-36 (2017)

7. G.I. Grinfeld, Comparative tests of autoclaved aerated concrete masonry with different designs of masonry seam / G.I. Grinfeld, A.P. Kharchenko // Housing construction. No. 11. - pp. 30-34 (2013)

8. A.S. Gorshkov, Properties of wall structures made of aerated concrete products of autocuring on polyurethane glue / A.S. Gorshkov, N.I. Batting // Engineering magazine. No. 5. pp. 5-19 (2013) 
9. A. Glumov Laying on polyurethane compounds: how to eliminate cold bridges / A. Glumov // Building materials, equipment and technologies of the XXI century. No. 4. - pp. 30-31 (2014)

10. Test methods for masonry. Part 5. Determination of bond strength by the bending moment method: STB EN 1052-5. - Introduction. 02/10/2015 - Minsk: State Standard of the Republic of Belarus - 12 p. (2015) 